\title{
腱板断裂に伴う烏口肩峰弓の破綻之骨頭の上方脱臼
}

\author{
熊本整形外科病院 \\ 浅 原 洋 資・北 村 歳 男 \\ 生田拓也・久賀 太 \\ 新垣和伸 $\cdot$ 出口力

\section{Coracoacromial Arch Failure and Superior Humeral Dislocation Following Massive Rotator Cuff Tear} \\ Yosuke Asahara, Toshio Kitamura, Takuya Ikuta, Futoshi Kuga, \\ Kazunobu Arakaki, and Chikara Deguchi \\ Department of Orthopaedic Surgery, Kumamoto \\ Orthopaedic Hospital, Kumamoto, Japan

\begin{abstract}
We reported three cases of coracoacromial arch failure and superior humeral dislocation in natural history following massive rotator cuff tear. They consisted of a 71-year-old male, 84-year-old female, and 72-year-old male with tenderness of the shoulder, hydrarthrosis, restriction of ROM, and or impression in the area in front of the acromion. Their X-ray, CT showed superior humeral dislocation and destruction of the acromion in the diagnostic imaging. There is no effective treatment for this disease. We report the role of coracoacromial ligament and the pathology of coracoacromial arch failure in natural history following massive rotator cuff tear.
\end{abstract}

Key words : coracoacromial ligament (烏合肩峰勒帯), superior humeral dislocation (上腕骨頭上方 脱臼), rotator cuff tear (腱板断裂)

\section{は じめに}

腱板断裂の長期経過後, 骨頭の上方偏位が進行し肩 峰が破壊消失したと考えられる3 症例を経験した。過 去に, 手術時の鳥口肩峰勒带 (以下 C-A ligament) 切除に伴う骨頭の上方化の報告 ${ }^{4)}$ はあるが，自検例は 自然経過にて同様の状態を呈した。今回, この経験を むとに，烏合肩峰弓（以下 C-A arch）などの骨頭上 方化の抑制機構について検討した。

\section{症 例 供 覧}

3 症例の主訴, 病歴, 検查所見などは類似しており, まとめて呈示する.

【症例】症例 $1: 71$ 歳, 男性, 症例 $2: 84$ 歳, 女性,
症例 $3: 72$ 歳, 男性.

【主訴】肩痛，拳上困難，関節水腫.

【既往歷】症例 $1:$ 脊䯣小脳変性症。症例 2,3 : な L.

【現病歷】数年前より症状出現し, 近医にて保存的治 療を行うも症状改善なく当院受診.

【所見】視診にて骨頭の前上方への突出と関節水腫を 疑わせる腫脹を認めた。触診では肩峰前方部に骨性成 分は触れず，陥凹があった。自動挙上は不能.

【関節液検查】症例 1 を除く 2 例に施行し, 色調は黄 色透明, 培養結果は negative. 白血球が存在する以 外に特記する所見はなかった。

【血液検查】症例 $1:$ 未施行, 症例 $2 ： \mathrm{WBC}: 4800 /$ $\mathrm{mm}^{3}, \mathrm{CRP}: 0.0 \mathrm{mg} / \mathrm{dl}$, 症例 $3: \mathrm{WBC}: 4510 / \mathrm{mm}^{3}$, 


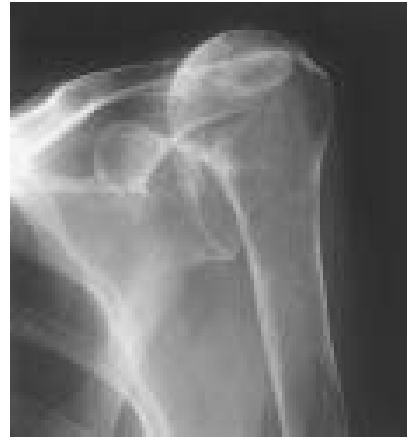

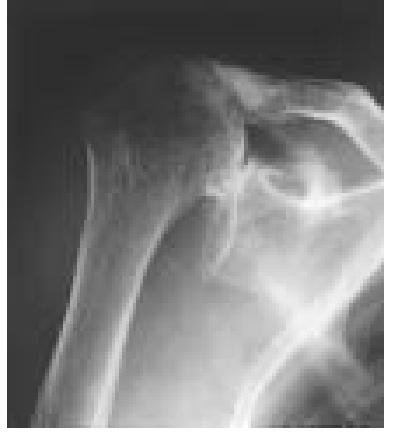

b

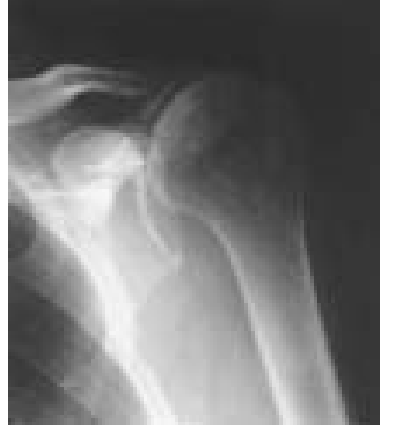

c

図 1 単純 X 線：骨頭が上方脱臼し，肩鎖関節に対し migration の状態
a 症例 1
$\mathrm{b}$ 症例 2
c 症例 3

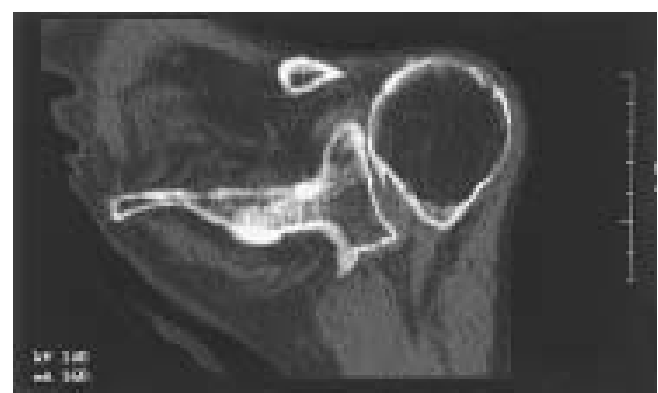

a

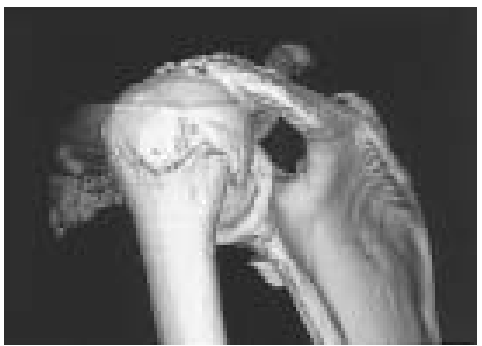

\section{CRP : 0.1mg/dl}

【画像所見】 3 例とも単純 X 線では, 骨頭が上方に 偏位し，関節窩に対する上方脱臼を認めた，肩峰の前 縁は確認できなかった（図 1)。症例 1 の CT および 3 DCT では, 肩峰の前縁が粉砕骨折あるいは消失し た状態であった（図 2 )。同様に症例 1 の MRI では

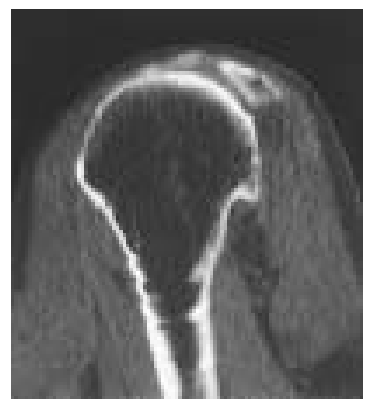

b
図 2 症例 1

a, b CT

c $3 \mathrm{DCT}$

骨頭の上方化, 肩峰の粉砕, 消失.
骨頭の上方化，肩峰の消失，更に腱板の広範囲断裂や 脂肪変性を認めた（図 3 ).

【治療】症例 $1 ， 2$ に対しては, 高齢で ADL 屯低い ため保存的治療を行っているが症状の軽減はない，症 例 3 は, 林業に従事されている活動性の高い症例で, 痛みに対し手術治療を強く希望された。造影䨩を併用 


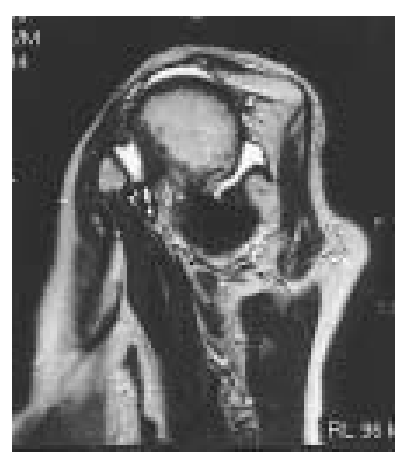

a

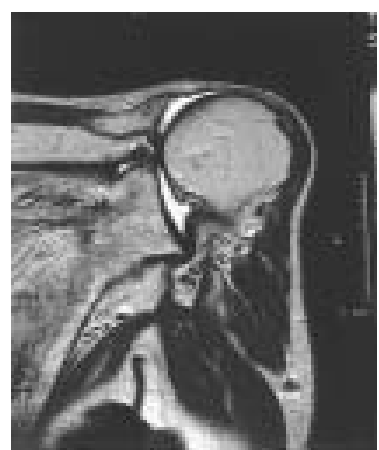

b

図 3 症例 1

$\mathrm{a}, \mathrm{b}$ MRI

骨頭の上方化, 肩峰の消失, 腱板の広範囲断裂や脂肪变性を認める.

表 1 鑑別診断

- 腱板断裂性肩関節症 (cuff tear arthropathy)

- Milwaukee shoulder

・ステロイド関節症

- 偽痛風

・变形性肩関節症

・化膿性肩関節炎

- Charcot 関節

- RA

したブロックテストで一時的な痛みの改善を認めたた め, 鏡視下に滑膜のみのデブリードマンを行ったが, 効果は見られなかった。鏡視上は C-A ligament の同 定は出来なかった。

考察

腱板断裂の長期経過後，骨頭の上方偏位が進行し肩 峰が破壊消失したと考えられる 3 症例を経験した。今 回の 3 症例の特記すべきは, その希な病歴と病態であ るが，これらがどのようにして生じたのか，発症機序 について検討した.

鑑別診断としては，表 1 に示す通りであるが，その 中では cuff tear arthropathy が最も近いと考える. ただし, Neer らの提唱した定義 ${ }^{3)}$ では, それは大断 裂例で上腕骨頭の collapse をもつ関節症としており, 自検例では関節症变化としての骨頭の変形がないため 矛盾する，つまり，自検例は今までの疾患概念では説 明のつかない病態であると考えられる.
過去の報告では，腱板縫合術後の合併症として生じ た骨頭上方化の報告があった. Wiley ${ }^{4)}$ が腱板大断裂 の縫合術にて C-A ligament 切除を行い, その結果骨 頭上方転位を生じた 4 例について報告している。その 後, Lee ${ }^{2)}$ が解剖体を用いて, C-A ligament 切除 後の骨頭偏位を報告. Hockman ら ${ }^{2)}$ は解剖体を用い て, 人工骨頭術後の C-A ligament の役割を検討し, 骨頭の前上方偏位への抑制因子として作用しているこ とを証明した．以上のように，C-A ligament を切除 した結果, 骨頭偏位を生じた報告はある。しかし, 自 検例のように腱板断裂の自然経過においても，C-A ligament が損傷し最終的に肩峰破壊を生じたという 報告はない。我々は，自検例に扔いても C-A ligament を含めた C-A arch の機能破綻が病態の中心と 考えた.

我々の考察する発生機序としては, 腱板の広範囲断 裂の長期自然経過に伴い，三角筋による骨頭の引き上 げ作用や肩甲下筋腱，棘下筋腱の断裂，上腕二頭筋長 頭腱の断裂などによって骨頭の上方化が進行し，それ による慢性的な機械的刺激が生じる.その結果, C-A ligament を含めた C-A arch が損傷することで，骨 頭偏位は更に進行し, 遂には肩峰が破壊, 消失したと 考える.

この病態に対する治療法については，投薬や関注な どの症状に応じた保存的治療が原則と考えるが，その 効果は一時的である。 そこで手術治療の検討を行った が, 腱板縫合はその脂肪変性と退縮の状態から効果は 期待できない，また，鏡視下デブリードマンは自検例で 
は無効であった。 疼痛の軽減を目標とするならば, C-A ligament の再建を検討すべきであるが，Wiley ${ }^{4)}$ は 4 例中 2 例に腸骨を用いて C-A ligament の再建を行 い, 脱曰整復と疼痛改善を得たが可動域制限は改善は 見られなかった。このようにC-A ligament の再建に 関しては，過去の報告む少なく確立された手術法では ないため施行は困難と思われる。つまり，この状態に 到達してしまうと, 有効な治療法はないのが現状であ る. 腱板断裂の診断, 治療の更なる向上を図るのは当 然ながら， C-A ligament を含めた C-A arch こそが, 骨頭の上方偏位を抑制する重要な組織であるという認 識を持つことが重要である．腱板断裂の手術時に CA ligamentの処置を行う際は, その適応を十分に考 慮したうえで, 切離後には可及的な解剖学的修復を目 指す必要があると思われる。

\section{結語}

(1) 現在まで報告のない, 腱板断裂の長期自然経過例 で，骨頭が上方偏位し肩峰が破壊消失した 3 症例を
経験した。

(2) 原因として, C-A ligament を含めた C-A arch の破綻が病態の中心と考察する.

(3) C-A ligamentは，骨頭の上方偏位を抑制する重 要な組織である.

(4) 手術時に, C-A ligament の処置は慎重に行う必 要がある.

\section{参 考 文 献}

1) Hockman, D. E., Lucas, G. L., Roth, C. A. : Role of the Coracoacromial Ligament as Restraint after Shoulder Hemiarthroplasty. Clin. Orthop., 419: 80-82, 2004.

2) Lee, T. Q., et al. : Release of the coracoacromial ligament can lead glenohumeral laxity : A biomechanical study. J. Shoulder Elbow Surg., 10 : 68-72, 2001.

3) Neer, C., et al. : Cuff-tear arthropathy. J. Bone Joint Surg., 65-A : 1232-1244, 1983.

4) Wiley, A. M. : Superior Humeral Dislocation. Clin. Orthop., $263:$ 135-141, 1991. 